sities embodied in the Higher Education Act of 1977 encourages the recruitment of adult students, while the syllabus structure facilitates the staggering of courses over a longer time-scale to accommodate, for example, family commitments. It is not

\section{Nuclear safety}

\section{Action soon on thermal shock}

Washington

The US Nuclear Regulatory Commission (NRC) may soon act to require eventual modifications in older pressurized water reactors to reduce the risk of potentially disastrous ruptures in the reactor vessel. A recently completed study by the staff of NRC's Advisory Committee on Reactor Safeguards (ACRS) showed ten plants that may need such modifications between now and the year 2000. At least some of these plants may be forced to make a choice between very expensive modifications or closing before their originally anticipated useful life is up.

A rupture can occur when the steel reactor vessel, which in older plants tends to become brittle as a result of exposure to radiation, is quickly cooled while kept under pressure. This would happen if a small break in the primary cooling system (which runs through the vessel and then a heat exchanger to produce steam in a secondary loop) occurred and cold emergency core cooling water were pumped in, or similarly if emergency feedwater were pumped into the secondary system because of a leak there. In either case, the water in the primary loop would cool off quickly while the pressure remained close to its normal high level. As the inside of the 8-inch thick walls of the vessel cooled, the resulting stresses could aggravate an existing flaw, resulting in a surface crack; the high internal pressure could then drive the crack completely through the vessel wall. In the worst case, the core cooling water would be lost and the core would melt.

Although this problem of "pressurized thermal shock" has been recognized for some time, two recent discoveries have fuelled concern. Test results from samples placed in reactors have shown over the past few years that the embrittlement from radiation is proceeding faster than previously thought. The second discovery came in an analysis of the 1978 Rancho Seco accident (in which a partial power failure in the instrumentation caused a valve in the steam generator to be opened, leading to overcooling of the core) which concluded that if the plant had been older, a rupture could have occurred.

How much cooling it takes to make a crack grow in the reactor vessel depends on a property of the metal referred to as its reference temperature. This is the temperature at which the vessel, when cooling, changes rapidly from ductile to brittle behaviour. As the reactor vessel gets older only school-leavers, therefore, who-are resorting to the universities, according to the Stockholm daily Svenska Dagbladed, more than half the students in Stockholm are now over thirty years of age, and nearly a quarter of them over forty. Vera Rich

- that is, as it is exposed longer to radiation - the reference temperature climbs.

The ACRS staff has recommended no absolute cut-off on acceptable reference temperatures; rather, they have proposed a "screening criterion". When the welds (the critical spots, because they contain a small amount of copper) that run along the length of the vessel reach a reference temperature of $130^{\circ} \mathrm{C}$, or the welds that run around the circumference reach a reference temperature of $150^{\circ} \mathrm{C}$, a more thorough analysis of the plant would be made to determine what should be done. This criterion was established because of the ultimate probability of a core melt. Operating experience suggests that an overcooling accident in which the temperature in the primary loop falls below $150^{\circ} \mathrm{C}$ can be expected once every 100 reactor-years. (The normal operating temperature of the fluid is $290^{\circ} \mathrm{C}$.)

No reactors exceed the screening criterion yet, but five are expected to by 1988-1990.

The possible solutions proposed are reducing the radioactive flux reaching the reactor vessel by placing the older fuel elements on the outer ring of the core, modifying the control system automatically to depressurize the primary system as it cools, increasing the temperature of the emergency core cooling water and emergency feedwater, and even annealing the vessel to restore its ductility (which would require removing the core, drying out the vessel and inserting an electric heating grid to raise the vessel's temperature to $450^{\circ} \mathrm{C}$ for a week).

The ACRS staff recommendation does not propose any across-the-board solution, though. According to staff member Roy Woods, "it's a plant-specific problem"'. Three years before a plant would reach the screening level, it would have to submit a plan for approval by NRC.

Critics have been quick to point out the large uncertainties in the screening criterion, something that the ACRS staff concedes while maintaining that they have been conservative in their calculations. Robert Pollard of the anti-nuclear Union of Concerned Scientists said also that NRC has never systematically looked for conditions that could lead to pressurized overcooling. "The only part of the thing that is certain," he said, "is that if the vessel ruptures the emergency core cooling system can't prevent melting of the core. The only protection is preventing it from occurring",
Social science research

\section{Debates go on}

The British Social Science Research Council (SSRC) will not, after all, be disbanded but instead will have its budget cut. Sir Keith Joseph, the Secretary of State for Education and Science, announced earlier this week that he had decided to reduce by $£ 6$ million the recommendation of the Advisory Board for the Research Councils (ABRC) that SSRC should have $£ 73$ million to spend in the three years from next April. By doing so, he reminded everybody who is the boss, but has also ensured that arguments will continue about the functions of advisory committees whose advice is rejected before it is made public.

The SSRC budget has become a contentious issue in the desultory argument about the support of British academic research. Just over a year ago, Sir Keith triggered off an argument about academic autonomy by announcing that he would cut $£ 500,000$ from the present annual budget of SSRC and that he had asked Lord Rothschild to inquire into its functions and to report. The subsequent discovery (by means of private letters between Sir Keith and the Chancellor of the Exchequer published by New Society) that Sir Keith was unsympathetic to social science research seems not to have cast him down.

Sir Keith was at pains this week to emphasize that his decree is less generous than the Rothschild recommendation (in May this year) of a frozen budget (in real terms) He has also asked the council to consider changing its name and to shift more of its support for graduate students (now running at 45 per cent or $£ 8.8$ million per year) from quotas awarded to university departments to awards to students who would then choose where to study.

Earlier this week, Sir Keith insisted that social problems were important, that SSRC spent only one-eighth of the government's total expenditure in this field but that the social sciences differ from the natural sciences in that the results of social science research are not "falsifiable". "You cannot prove that a scientific theory is correct, but you can carry out experiments to prove it wrong.",

On balance, SSRC is likely to be relieved by the way things have turned out. By some accounts, even after the publication of Lord Rothschild's recommendation that the council should be kept going, SSRC's chairman Mr Michael Posner has spent a summer of disquiet. said on Monday that he did not question Sir Keith Joseph's right to countermand ABRC's advice, but that he thought Sir Keith had been influenced by people "who try to have it both ways".

The next instalment in this saga will be on 27 October, when ABRC is to be allowed to publish its latest advice to the British government. 